\title{
Lars Bovenberg, Casper van Ewijk and Ed Westerhout (eds.) (2012). The Future of Multi-Pillar Pensions. Cambridge, UK: Cambridge University Press, 434 pp. ISBN 9781107022263 (hardback)
}

\author{
ReVIeWed by DaVid Hollanders*
}

In 1994, The World Bank report Averting the Old Age Crisis which proposed three pension pillars initiated a lively public- and academic debate regarding ageing and pensions. The Future of Multi-Pillar Systems bringing together 11 chapters of 15 authors - aims to assess what has come of that debate and to reconsider "the multi-pillar pension scheme against the background of demographic and other trends and a severe financial and debt crisis."

Hinz, a World Bank-affiliated author, pictures the current World Bank position, which is essentially unaltered. Pension systems have three functions (corresponding with the three pillars): redistribution, including poverty alleviation; insurance; and consumption smoothing. Hinz proposes that individual savings or privately managed accounts are more efficient. This may deepen capital markets.

Other authors state that individual accounts face difficulties. Bodie and Prast point out that most participants lack financial knowledge, postpone decision making, and are influenced by framing. Just as citizens do not have to operate by themselves when sick, they should be able to leave

* David Hollanders, Department of Finance, Tilburg University, Tilburg, The Netherlands 
International Journal of Ageing and Later Life

investment decisions to experts. According to Bodie and Prast, however, there should be some broad and easily understandable choices related to investments' risk profiles. Another author, Barr, does not focus on the demand side (i.e. participants) of the pension market but instead on pension plan providers. Individual plans are prone to agency risks, including fraud and misalignment of incentives of fund managers and plan participants. This does not mean that defined-benefit plans, guaranteed by a sponsoring employer, are the solution. Barr states that "a cynical view is that in corporate plans the firm creams the surplus in good times and reneges on pension promises in bad times," leading to a false sense of security.

An alternative for employer-led collective plans and individual pension plans is an increased government role. Contributing co-editors Bovenberg and van Ewijk point out that in an efficient pension system, risks are shared by all citizens. If the system is optimal, people with a low income (if risk-aversion is income-dependent) as well as the elderly (habit-formation) should be exposed to relatively small risks. Collective, nationwide risksharing suggests a role for the government. The government is also crucial in at least another respect. Several authors, for example Bohn, point out that macro-risks can only be shared between - but not within generations. This however implies that participation of an ex-ante efficient pension scheme needs to be mandatory. Otherwise, young participants might want to leave a risk-sharing pension scheme after a negative financial shock, as ex-ante efficiency leads to ex-post redistribution. Only governments can impose mandatory participation. However, the government may also abuse its powers. There is thus a trade-off between intergenerational risk sharing (which is efficient) and government involvement (which may be inefficient). Authors Beetsma and Bucciol present simulations regarding another role that governments may play. The government can complete financial markets, by issuing inflation- and/or longevity-linked bonds that are not available on financial markets. The authors suggest that such bonds may improve efficiency.

Most chapters in the book focus on the second pillar (i.e. work-related supplementary pensions). This is generally a good choice as the first pillar (i.e. publicly provided basic pensions) has already been discussed at length, in research as well as in the wider public debate. The chapter about 
the first pillar indeed paints the well-known picture of aging and the negative implications that may have on public finance. However, one less well-known fact is also worked out. There is considerable variety in the extent that European countries age. In Denmark, for example, it is expected that by the year 2060, there will be 60 people aged 65 years and older for every 100 people aged between 15 and 64 years. In Ireland, this number is 37 , only slightly higher than the current number in Denmark.

Taken together, the book thus offers a variety of approaches and considerations. The World Bank position as well as several alternative views and perspectives are presented. As such, the book achieves its goal to reconsider the pension debate. Given the different evaluations of individual pension plans - which is the corner stone of the World Bank proposal as well as the route many countries are taking - it would have been interesting if different authors could have directly reacted to one another. In the absence of a discussion between authors, the reader in the end has to make up his or her own mind about the current state of pension affairs and preferable policies. The contribution of this book, however, lies in providing the reader with the perspectives and approaches to do so in an informed manner. 